\title{
ОСОБЛИВОСТІ ДЕПРЕСИВНИХ РОЗЛАДІВ У ХВОРИХ НА РОЗСІЯНИЙ СКЛЕРОЗ
}

\section{Негрич Т. І., Кирилюк С. Я.}

\section{ВСТУП}

Розсіяний склероз (РС) - хронічне прогресуюче демієлінізуюче захворювання центральної нервової системи, у клінічній картині якого поряд 3 вогнищевими неврологічними симптомами мають місце психічні порушення ${ }^{1}$ Спостерігаються афективні розлади депресивний синдром, неврозоподібні прояви, панічні розлади, астенічні, істеричні та істериформні реакції, обсесивні порушення 2 . Дослідження емоційної сфери виявляють високий рівень тривоги у сфері соціальних контактів, емоційну напруженість, незадоволеність життєвою ситуацією, ейфорію (зазвичай на пізніх стадіях хвороби), емоційну нестійкість ${ }^{3}$.

17,9-79\% пацієнтів із РС страждають на депресивні розлади ${ }^{4}$. Вони розвиваються на досить ранніх етапах РС, а близько $30 \%$ осіб

${ }^{1}$ Neuropsychiatric Symptoms of Multiple Sclerosis: State of the Art / C. Silveira et al. Psychiatry Investig. 2019. Vol. 16(12). P. 877, 878.

The incidence and prevalence of psychiatric disorders in multiple sclerosis: A systematic review / R.A. Marrie et al. Mult Scler. 2015. Vol. 21(3). P. 305.

${ }^{2}$ Neuropsychiatric Symptoms of Multiple Sclerosis: State of the Art / C. Silveira et al. Psychiatry Investig. 2019. Vol. 16(12). P. 877, 878.

The incidence and prevalence of psychiatric disorders in multiple sclerosis: A systematic review / R.A. Marrie et al. Mult Scler. 2015. Vol. 21(3). P. 305.

Старинець Н.Г. Фактори суїцидальності при множинному склерозі. Міжнародний неврологічний журнал. 2013. № 6(60). С. 60.

Шмидт Т.Е., Яхно Н.Н. Рассеяный склероз. Москва : Медпресс-информ, 2012. С. 62.

Arnason B., Fredrikson S. Cognition in Multiple Sclerosis. Proceedings of the MS Forum Modern Management Workshop. Budapest. 2008. P. 23.

${ }^{3}$ Старинець Н.Г. Вказана праця. С. 60.; Шмидт Т.Е., Яхно Н.Н. Вказана праця. C. 62.; Arnason B., Fredrikson S. Вказана праця. Р. 23.

${ }^{4}$ Neuropsychiatric Symptoms of Multiple Sclerosis: State of the Art / C. Silveira et al. Psychiatry Investig. 2019. Vol. 16(12). Р. 877, 878.; Шмидт Т.Е., Яхно Н.Н. Вказана праця. С. 62.; Prevalence of depression and anxiety in Multiple Sclerosis: A systematic review and meta-analysis / R.E. Boeschoten et al. J Neurol Sci. 2017. Vol. 372. P. 331.; Chiaravalotti N.D., DeLuca J. Когнитивные нарушения при рассеянном склерозе. The Lancet neurology Ukrainian edition. 2009. № . 2(11). C. 42.; Depression in multiple sclerosis / S. Mrabet, N. Ben Ali, M. Kchaou, S. Belal. Rev Neurol (Paris). 2014. Vol. 170(11). P. 701.; Solaro C., Gamberini G., Masuccio F.G. Depression in Multiple Sclerosis: Epidemiology, Aetiology, Diagnosis and Treatment. CNS Drugs. 2018. Vol. 32(2). P. 118.; Suicidal ideation, anxiety, and depression in patients with multiple sclerosis / C.B. Tauil et al. Arq Neuropsiquiatr. 2018. Vol. 76(5). P. 297. 
мають симптоми депресії ще до встановлення діагнозу. Попри значну поширеність депресії у пацієнтів з РС, часто ії прояви не виявляються i не лікуються належним чином. Одною 3 причин цього $\epsilon$ те, що лікарі в повсякденній діяльності не проводять опитування хворих, та й пацієнти не висловлюють скарги відповідного характеру.

Депресивні прояви $є$ важливою детермінантою якості життя при РС, оскільки нейропсихологічні розлади значною мірою порушують функціонування хворих ${ }^{5}$. Наявність депресії у пацієнтів з РС погіршує інші неврологічні симптоми, заважає справлятися 3 повсякденною діяльністю, здійснює негативний вплив на стосунки та спілкування з оточуючими, знижує когнітивні функції та продуктивність праці ${ }^{6}$.

Клінічно депресія проявляється наявністю більше двох тижнів наступних симптомів: присутність смутку чи дратівливості, втрата зацікавленості і задоволення від повсякденної діяльності, розлади харчової поведінки (зниження чи збільшення апетиту), порушення сну, ажитація, втома, відчуття провини та нікчемності, проблеми 3 мисленням і концентрацією уваги, наявність суїцидальних думок ${ }^{7}$. Помічено високий рівень схильності до суїциду (до 29,4\%) та спроб суїциду $(6,4 \%)$ у пацієнтів з PC $^{8}$. Ці показники в два рази вищі, ніж у загальній популяції.

${ }^{5}$ Neuropsychiatric Symptoms of Multiple Sclerosis: State of the Art / C. Silveira et al. Psychiatry Investig. 2019. Vol. 16(12). P. 878.

Arnason B., Fredrikson S. Cognition in Multiple Sclerosis. Proceedings of the MS Forum Modern Management Workshop. Budapest. 2008.P. 23.

Disability worsening among persons with multiple sclerosis and depression: A Swedish cohort study / S. Binzer et al. Neurology. 2019. Vol. 93(24). P. e2221.

${ }^{6}$ Disability worsening among persons with multiple sclerosis and depression: A Swedish cohort study / S. Binzer et al. Neurology. 2019. Vol. 93(24). P. e2221.

${ }^{7}$ Siegert R.J, Abernethy D.A. Depression in multiple sclerosis: a review. J Neurol Neurosurg Psychiatry. 2005. Vol.76. P. 469.

${ }^{8}$ Старинець Н.Г. Фактори суїцидальності при множинному склерозі. Міжнародний неврологічний журнал. 2013. № 6(60). С. 61.

Disability worsening among persons with multiple sclerosis and depression: A Swedish cohort study / S. Binzer et al. Neurology. 2019. Vol. 93(24). P. e2221.

Siegert R.J, Abernethy D.A. Вказана праця. P. 471.

Multiple sclerosis and risk of attempted and completed suicide - a cohort study / P. Brenner et al. Eur J Neurol. 2016. Vol. 23(8). P. 1329.

Feinstein A., Pavisian B. Multiple sclerosis and suicide. Mult Scler. 2017. Vol. 23(7). P. 924.

Association between suicide and multiple sclerosis: An updated meta-analysis / Q. Shen et al. Mult Scler Relat Disord. 2019. Vol. 34. P. 86. 
Попри певні досягнення у вивченні етіопатогенезу депресивних розладів при РС, дані літератури з цього питання є неоднозначними. Більшість дослідників відзначають, що поширеність депресії при РС $\epsilon$ вищою у порівнянні з іншими неврологічними захворюваннями 9 Депресія при РС має мультифакторіальне походження і включає психологічні, соціальні, нейробіологічні, імунологічні та генетичні чинники ${ }^{10}$. Проте до кінця не з'ясовано, чи депресивні порушення $\epsilon$ наслідком основного захворювання або ж психологічної реакції на саму хворобу. Згідно з одними літературними джерелами депресія розглядається як реакція на стресовий вплив РС на функціонування пацієнтів, згідно 3 іншими - депресивні розлади $є$ наслідком прогресуючої інвалідизації. Спираючись на кореляційні зв'язки між показниками депресивних проявів та даними магнітно-резонансної терапії, підтверджено, що причиною депресії $\epsilon$ ураження центральної нервової системи ${ }^{11}$. Важливим також $\epsilon$ те, що депресивні прояви можуть розвиватися i внаслідок прийому патогенетичної терапії, а саме бета-інтерферонів ${ }^{12}$.

Вважається, що депресія частіше трапляється у хворих з рецидивуючо-ремітуючим перебігом РС (РP РC), ніж вториннопрогресуючим (ВП РС). За даними інших досліджень, депресивні порушення мають місце при усіх ступенях фізичної неспроможності пацієнтів і не залежать від типу перебігу та тривалості захворювання ${ }^{13}$. Також існують докази того, що прогресуючий перебіг патологічного процесу характеризується вищим рівнем депресивної симптоматики, на відміну від РP РС та клінічно ізольованого синдрому ${ }^{14}$.

9 Данилова М.В. Депрессивные расстройства у больных рассеянным склерозом (Обзор литературы). Український вісник психоневрології. 2012. Том 20. Вип. 1 (70). С. 55.

10 Старинець Н.Г. Оцінка емоційно-особистісних характеристик у хворих на множинний склероз. Украӥнський неврологічний журнал. 2011. № 1(18). С. 66.

11 Данилова М.В. Депрессивные расстройства у больных рассеянным склерозом (Обзор литературы). Украӥнський вісник психоневрологї̈. 2012. Том 20. Вип. 1 (70). С. 55.

${ }^{12}$ Neuropsychiatric Symptoms of Multiple Sclerosis: State of the Art / C. Silveira et al. Psychiatry Investig. 2019. Vol. 16(12). P. 878.

${ }^{13}$ Старинець Н.Г. вказана праця. С. 66.

Шмидт Т.Е., Яхно Н.Н. Рассеяный склероз. Москва : Медпресс-информ, 2012. С. 62.

Depression in multiple sclerosis / S. Mrabet, N. Ben Ali, M. Kchaou, S. Belal. Rev Neurol (Paris). 2014. Vol. 170(11). P. 702.

${ }_{14}$ Шмидт Т.Е., Яхно Н.Н. Вказана праця. С. 62; Solaro C., Gamberini G., Masuccio F.G. Depression in Multiple Sclerosis: Epidemiology, Aetiology, Diagnosis and Treatment. CNS Drugs. 2018. Vol. 32(2). P. 130. 
Мета роботи - вивчити особливості депресивних розладів у хворих на РС залежно від тривалості, перебігу захворювання та ступеня інвалідизації пацієнтів.

\section{1. Матеріали та методи дослідження}

За період з 2012 по 2015 роки на кафедрі нервових хвороб Львівського національного медичного університету імені Данила Галицького та у Львівському обласному науковому центрі 3 вивчення проблем розсіяного склерозу та інших демієлінізуючих захворювань, що знаходиться на базі Львівської обласної клінічної лікарні, було обстежено 65 пацієнтів 3 достовірним діагнозом РС згідно з критеріями Мак Дональда 2010.

Організація дослідження грунтувалася на положеннях Гельсінської декларації, відповідала етичним та морально-правовим вимогам згідно з наказом МОЗ України № 281 від 01.11.2000 р. та була затверджена комісією з питань біомедичної етики Львівського національного медичного університету імені Данила Галицького (протокол № 2 від 18 лютого 2013 р.). Від усіх хворих було отримано письмову інформовану згоду на участь у дослідженні.

Серед 65 паціснтів 67,69\% були жінки, 32,31\% - чоловіки. Середній вік хворих був достатньо зрілим та становив $37,17 \pm 1,33$ років, середня тривалість патологічного процесу $7,83 \pm 0,97$ років, а середній бал за шкалою інвалідизації (Expanded Disability Status Scale - EDSS) - 4,3 $\pm 0,17$. Серед обстежених осіб були пацієнти 3 PР PC $(58,46 \%)$, ВП РС (23,08\%), первиннопрогресуючим перебігом РС (ПП РС) (6,15\%) та в дебюті захворювання (12,31\%).

Усім пацієнтам проводили загальноклінічне, неврологічне дослідження, оцінювали вираженість депресивних проявів. Ступінь тяжкості неврологічного дефіциту визначали за допомогою шкали Expanded Disability Status Scale (EDSS), а наявність депресивних розладів - за шкалою-опитувальником депресії Бека (Beck А.T., 1961). Тест дозволяв прицільно оцінити не лише тяжкість депресії загалом, але й визначити вираженість окремих ії проявів. Визначали також бал за субшкалами шкали Бека - когнітивно-афективною (1-13 пункт) та соматичною (14-21 пункт).

Результати хворих на РС порівнювали 3 показниками 20-ти практично здорових осіб контрольної групи, серед яких було

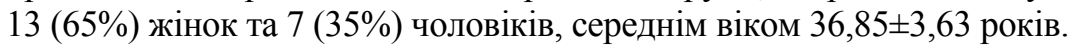


Для статистичного аналізу використовували програми Excel i Statistica 6.0. Розраховували середнє арифметичне і стандартну похибку. Ступінь вірогідності визначали за допомогою t-критерію Стьюдента, а при малих кількостях осіб у порівнювальних групах додатково здійснювалась перевірка за допомогою критеріїв МаннаУітні та Вілкоксона. Для встановлення взаємозв'язку між отриманими даними використовували критерій кореляції Пірсона та ранговий коефіцієнт кореляції Спірмена. За рівень статистичної вірогідності вважали результати при $р<0,05$.

\section{2. Результати та обговорення}

Особливості депресивних розладів у пацієнтів з РС, що вивчали за допомогою опитувальника Бека, наведені в табл. 1.

Таблиця 1

Показники депресивних проявів у хворих на РС за даними опитувальника Бека порівняно з практично здоровими особами

\begin{tabular}{|l|c|c|}
\hline \multicolumn{1}{|c|}{ Досліджуваний показник } & $\begin{array}{c}\text { Контрольна } \\
\text { група (n=20) }\end{array}$ & $\begin{array}{c}\text { Хворі на PC } \\
\text { (n=65) }\end{array}$ \\
\hline Шкала Бека, бали & $2,90 \pm 0,68$ & $11,48 \pm 1,2^{*}$ \\
\hline Немає депресії, частка осіб (\%) & 100 & $58,46^{*}$ \\
\hline Легка депресія, частка осіб (\%) & 0 & $18,46^{*}$ \\
\hline $\begin{array}{l}\text { Депресія середньої тяжкості, } \\
\text { частка осіб (\%) }\end{array}$ & 0 & $12,31^{*}$ \\
\hline Тяжка депресія, частка осіб (\%) & 0 & $10,77^{* *}$ \\
\hline Когнітивно-афективна субшкала, бали & $1,45 \pm 0,33$ & $5,86 \pm 0,67^{*}$ \\
\hline Соматична субшкала, бали & $1,55 \pm 0,35$ & $5,51 \pm 0,56^{*}$ \\
\hline
\end{tabular}

Примітки: * - достовірна відмінність показників між досліджуваною та контрольною групами при $p<0,01$; ** - достовірна відмінність показників між досліджуваною та контрольною групами при $p<0,05$.

Як видно з табл. 1, середній бал шкали Бека у хворих на РС був достовірно вищим порівняно з практично здоровими особами $(11,48 \pm 1,2$ проти $2,90 \pm 0,68, \mathrm{p}<0,01)$. Більше ніж у половини обстежених $(58,46 \%)$ депресія як діагноз не була встановленою. Серед пацієнтів із цим розладом найбільшу частку складали особи з легкою депресією ( $<0,01$ проти контрольної групи). Частки хворих із середньої тяжкості та тяжкою депресією були практично рівними - 12,31\% (p<0,01 проти контрольної групи) та $10,77 \%$ 
$(\mathrm{p}<0,05) . \quad$ У структурі депресивних розладів важливе місце посідали як когнітивно-афективні, так і соматичні прояви, оскільки середні бали відповідних субшкал достовірно вищі у порівнянні 3 контрольною групою $(\mathrm{p}<0,01)$.

Опитувальник Бека дає можливість оцінити прояви окремих симптомів депресії. Детальний аналіз результатів тестування наведений у табл. 2.

Таблиця 2

Аналіз опитувальника депресії Бека у хворих на РС порівняно з практично здоровими особами

\begin{tabular}{|l|c|c|}
\hline \multicolumn{1}{|c|}{ Досліджуваний показник } & $\begin{array}{c}\text { Контрольна група } \\
\mathbf{( n = 2 0 )} \\
\text { частка осіб,\% }\end{array}$ & $\begin{array}{c}\text { Хворі на РС } \\
\mathbf{( n = 6 5 )} \\
\text { частка осіб,\% }\end{array}$ \\
\hline Настрій порушений & 0 & $60,0^{*}$ \\
\hline Песимізм & 25 & $55,38^{* *}$ \\
\hline Незадоволеність & 25 & $52,31^{* *}$ \\
\hline Відчуття провини & 30 & 29,23 \\
\hline Відчуття можливого покарання & 10 & $30,77^{* *}$ \\
\hline Відраза до самого себе & 0 & $24,62^{*}$ \\
\hline Ідеї самозвинувачення & 20 & 36,92 \\
\hline Суїцдальні думки & 0 & $10,77^{* *}$ \\
\hline Плаксивість & 5 & $38,46^{*}$ \\
\hline Дратівливість & 25 & $50,77^{* *}$ \\
\hline Порушення соціальних зв'язків & 5 & $35,38^{*}$ \\
\hline Нерішучість & 10 & $46,15^{*}$ \\
\hline Дисморфофобія & 0 & $29,23^{*}$ \\
\hline Відчуття неспроможності & 10 & $40,0^{*}$ \\
\hline Втрата працездатності & 0 & $64,62^{*}$ \\
\hline Порушення сну & 15 & $56,92^{*}$ \\
\hline Втомлюваність & 15 & $76,92^{*}$ \\
\hline
\end{tabular}

Примітки: * - достовірна відмінність показників між досліджуваною та контрольною групами при $p<0,01$; ** - достовірна відмінність показників між досліджуваною та контрольною групами при $p<0,05$.

Відчуття провини та ідеї самозвинувачення зустрічалися з такою ж частотою у хворих на РС, як і у практично здорових осіб (p>0,05), інші показники опитувальника виявилися достовірно вищими у порівнянні $з$ контрольною групою $(\mathrm{p}<0,05)$. Найчастіше в обсте- 
жених спостерігалися втомлюваність, втрата працездатності, порушення настрою та сну, відчуття песимізму, незадоволеності, дратівливості, нерішучості, неспроможності. Найменше осіб було з суїцидальними думками, відразою до самого себе та дисморфофобією.

Прогресуючий перебіг, більша тривалість РС та тяжчий ступінь інвалідизації пацієнтів свідчать про значну активність патологічних процесів при цьому захворюванні. 3 метою встановлення значення цих показників у вираженості депресивних проявів при РС досліджували залежність депресивної симптоматики від ступеня інвалідизації обстежених, тривалості та перебігу захворювання.

За тривалістю перебігу РС усіх хворих поділили на 4 групи: до 1-го року, 1-5 років, 6-10 та понад 10 років. У табл. 3 представлені показники депресивних розладів залежно від тривалості патологічного процесу при цьому захворюванні.

Таблиця 3

Показники депресивних розладів хворих на РС залежно від тривалості захворювання та порівняно

3 контрольною групою

\begin{tabular}{|c|c|c|c|c|c|}
\hline Показник & $\begin{array}{c}\text { Контрольна } \\
\text { група } \\
(\mathbf{n}=\mathbf{2 0})\end{array}$ & $\begin{array}{c}1 \text { група } \\
\text { до } 1 \text { року } \\
(\mathbf{n}=8)\end{array}$ & $\begin{array}{l}2 \text { група } \\
1-5 \text { p. } \\
(n=24)\end{array}$ & $\begin{array}{l}3 \text { група } \\
6-10 \text { p. } \\
(n=18)\end{array}$ & $\begin{array}{c}4 \text { група } \\
\text { понад 10 p. } \\
(\mathrm{n}=15)\end{array}$ \\
\hline $\begin{array}{l}\text { Шкала Бека, } \\
\text { бали }\end{array}$ & $2,9 \pm 0,68$ & $\begin{array}{c}8,67 \pm \\
2,52^{* *}\end{array}$ & $\begin{array}{c}10,78 \pm \\
1,71^{*}\end{array}$ & $\begin{array}{c}12,59 \pm \\
2,36^{*}\end{array}$ & $\begin{array}{l}11,73 \pm \\
3,15^{* *}\end{array}$ \\
\hline \begin{tabular}{l|} 
Немає \\
депресії, \\
частка осіб (\%) \\
\end{tabular} & 100 & $66,67^{* *}$ & $60,87 *$ & $52,94 *$ & $60 *$ \\
\hline $\begin{array}{l}\text { Легка } \\
\text { депресія, } \\
\text { частка осіб (\%) }\end{array}$ & 0 & 22,22 & $21,74 * *$ & 17,65 & 13,33 \\
\hline $\begin{array}{l}\text { Депресія } \\
\text { середньої } \\
\text { тяжкості, } \\
\text { частка осіб (\%) }\end{array}$ & 0 & 0 & 8,7 & $23,53 * *, \#$ & 13,33 \\
\hline $\begin{array}{l}\text { Тяжка } \\
\text { депресія, } \\
\text { частка осіб (\%) } \\
\end{array}$ & 0 & 11,11 & 8,7 & 5,88 & 13,33 \\
\hline $\begin{array}{l}\text { Когнітивно- } \\
\text { афективна } \\
\text { субшкала, бали }\end{array}$ & $1,45 \pm 0,33$ & $4 \pm 1,45$ & $5,43 \pm 0,91 *$ & $6,71 \pm 1,31^{*}$ & $6,07 \pm 1,81 * *$ \\
\hline
\end{tabular}


Продовження таблиці 3

\begin{tabular}{|l|c|c|c|c|c|}
\hline $\begin{array}{l}\text { Соматична } \\
\text { субшкала, } \\
\text { бали }\end{array}$ & $1,55 \pm 0,35$ & $\begin{array}{c}4,67 \pm \\
1,18^{* *}\end{array}$ & $5,3 \pm 0,83^{*}$ & $5,47 \pm 1,16^{*}$ & $\begin{array}{c}5,73 \pm \\
1,37 * *\end{array}$ \\
\hline $\begin{array}{l}\text { Настрій } \\
\text { порушений, } \\
\text { частка осіб (\%) }\end{array}$ & 0 & $66,67 *$ & $43,48^{*}$ & $76,47^{*, \&}$ & $60^{*}$ \\
\hline $\begin{array}{l}\text { Песимізм, } \\
\text { частка осіб (\%) }\end{array}$ & 25 & 22,22 & $56,52^{* *}$ & $64,71^{* *, *}$ & $60^{* *,}$, \\
\hline $\begin{array}{l}\text { Порушення } \\
\text { соціальних } \\
\text { зв'язків, частка } \\
\text { ссіб (\%) }\end{array}$ & 5 & 11,11 & $39,13^{*}$ & $29,41^{* *}$ & $46,67^{*, \delta}$ \\
\hline
\end{tabular}

Примітки: * - достовірна відмінність показників між досліджуваними $i$ контрольною групами при $p<0,01$; ** - достовірна відмінність показників між досліджуваними і контрольною групами при $p<0,05$; відмінність показників між 1 i 3 групами при $p<0,05$; \& - достовірна відмінність показників між 2 і 3 групами при $p<0,05 ;{ }^{\delta}$ - достовірна відмінність показників між 1 i 4 групами при $p<0,05$.

Аналізуючи дані, наведені у табл. 3, видно, що депресивні порушення 3 початку захворювання характеризувалися соматичними проявами та розладами настрою. Це підтверджено вищими середніми балами шкали Бека, соматичної субшкали та частки осіб з порушеним настроєм, а також меншою часткою пацієнтів без депресії уже 3 початку РС порівняно 3 контрольною групою $(\mathrm{p}<0,05)$. Серед обстежених більшість осіб була з депресією легкого ступеня тяжкості (табл. 1), при цьому частка хворих 3 легкою депресією переважала за тривалості РС 1-5 років порівняно 3 практично здоровими особами $(\mathrm{p}<0,05)$, а кількість пацієнтів 3 депресією середньої тяжкості була більшою при тривалості патологічного процесу 5-10 років, на відміну від контрольної групи та обстежених з тривалістю хвороби до одного року $(\mathrm{p}<0,05)$.

Уже через рік від початку захворювання до клінічної картини депресивних розладів приєдналися когнітивно-афективні прояви, відчуття песимізму, порушилися соціальні зв'язки, про що свідчило зростання цих показників при тривалості РС понад один рік порівняно з контрольною групою $(\mathrm{p}<0,05)$.

Встановлено, що при зростанні тривалості захворювання посилення депресивних проявів у пацієнтів з РС відбувалося за рахунок розладів настрою, відчуття песимізму та, відповідно, страждали соціальні зв’язки. При тривалості патологічного процесу 
понад 5 років частка обстежених 3 відчуттям песимізму була більшою, ніж при тривалості до року, а за наявності хвороби 5-10 років переважали особи 3 розладами настрою порівняно 3 тривалістю $1-5$ років $(\mathrm{p}<0,05)$. Частка пацієнтів 3 порушеними соціальними зв'язками була вищою при тривалості РС понад 10 років, ніж до року $(\mathrm{p}<0,05)$.

Таблиця 4

Показники депресивних розладів хворих на РС залежно від ступеня інвалідизації за шкалою EDSS та порівняно з контрольною групою

\begin{tabular}{|c|c|c|c|c|}
\hline Показник & $\begin{array}{c}\text { Контрольна } \\
\text { група } \\
(\mathbf{n}=\mathbf{2 0})\end{array}$ & $\begin{array}{c}1 \text { група } \\
\text { бал 0-3,5 } \\
(\mathrm{n}=24)\end{array}$ & $\begin{array}{c}2 \text { група } \\
\text { бал 4-5,5 } \\
(\mathrm{n}=30)\end{array}$ & $\begin{array}{c}3 \text { група } \\
\text { бал 6-9,5 } \\
(\mathrm{n}=11)\end{array}$ \\
\hline Шкала Бека, бали & $2,9 \pm 0,68$ & $9 \pm 1,65^{*}$ & $\begin{array}{l}14,42 \pm \\
2,06^{*}, \#\end{array}$ & $\begin{array}{l}12,45 \pm \\
3,41 * *\end{array}$ \\
\hline $\begin{array}{l}\text { Немає депресії, } \\
\text { частка осіб (\%) }\end{array}$ & 100 & $70 * *$ & $51,61 *$ & $29,41^{*, \&}$ \\
\hline $\begin{array}{l}\text { Легка депресія, } \\
\text { частка осіб (\%) }\end{array}$ & 0 & 15 & $12,9 * *$ & 23,53 \\
\hline $\begin{array}{l}\text { Депресія середньої } \\
\text { тяжкості, частка осіб (\%) }\end{array}$ & 0 & 10 & $19,35^{* *}$ & $0^{\delta}$ \\
\hline $\begin{array}{l}\text { Тяжка депресія, } \\
\text { частка осіб (\%) }\end{array}$ & 0 & 5 & $16,13^{* *}$ & 11,76 \\
\hline $\begin{array}{l}\text { Когнітивно-афективна } \\
\text { субшкала, бали }\end{array}$ & $1,45 \pm 0,33$ & $\begin{array}{l}4,25 \pm \\
0,97 * *\end{array}$ & $\begin{array}{l}7,58 \pm \\
1,13^{*, \#}\end{array}$ & $\begin{array}{l}6,27 \pm \\
1,79 * *\end{array}$ \\
\hline $\begin{array}{l}\text { Соматична субшкала, } \\
\text { бали }\end{array}$ & $1,55 \pm 0,35$ & $4,4 \pm 0,76^{*}$ & $\begin{array}{l}6,84 \pm \\
0,97 *\end{array}$ & $\begin{array}{l}6,18 \pm \\
1,66^{* *}\end{array}$ \\
\hline $\begin{array}{l}\text { Настрій порушений, } \\
\text { частка осіб (\%) }\end{array}$ & 0 & $40^{*}$ & $74,19^{\text {*,\# }}$ & $47,06^{*}$ \\
\hline Песимізм, частка осіб (\%) & 25 & 30 & 70,97*\#, & 47,06 \\
\hline $\begin{array}{l}\text { Відраза до самого себе, } \\
\text { частка осіб }(\%)\end{array}$ & 0 & 10 & $38,71 *$, & 11,76 \\
\hline $\begin{array}{l}\text { Відчуття } \\
\text { неспроможності, } \\
\text { частка осіб (\%) }\end{array}$ & 10 & 20 & $51,61 * \#$ & 41,18 \\
\hline
\end{tabular}

Примітки: * - достовірна відмінність показників між досліджуваними $i$ контрольною групами при $p<0,01$; ** - достовірна відмінність показників між досліджуваними і контрольною групами при $p<0,05$; ${ }^{\#}-$ достовірна відмінність показників між 1 i 2 групами при $p<0,05$; ${ }_{\text {- }}$ - достовірна відмінність показників між 1 i 3 групами при $p<0,05 ;{ }^{\delta}$ - достовірна відмінність показників між 2 і 3 групами при $р<0,05$. 
Таблиця 5

Показники депресивних розладів хворих на РС залежно від типу перебігу РС та порівняно з контрольною групою

\begin{tabular}{|c|c|c|c|c|c|}
\hline Показник & $\begin{array}{l}\text { Контрольна } \\
\text { група }(\mathbf{n}=\mathbf{2 0})\end{array}$ & $\begin{array}{c}1 \text { група } \\
\text { PP PC } \\
(\mathbf{n}=38) \\
\end{array}$ & $\begin{array}{c}2 \text { група } \\
\text { ВП РС } \\
(\mathrm{n}=15) \\
\end{array}$ & $\begin{array}{c}3 \text { група } \\
\text { ПП РС } \\
(\mathrm{n}=4)\end{array}$ & $\begin{array}{c}4 \text { група } \\
\text { дебют } \\
(\mathrm{n}=8) \\
\end{array}$ \\
\hline Шкала Бека, бали & $2,9 \pm 0,68$ & $\begin{array}{c}10,05 \pm \\
1,32 *\end{array}$ & $\begin{array}{c}17,87 \pm \\
3,3 *, \#, \&, \delta\end{array}$ & $\begin{array}{l}8,25 \pm \\
1,25^{*}\end{array}$ & $7,88 \pm 2,72$ \\
\hline $\begin{array}{l}\text { Немає депресії, } \\
\text { частка осіб (\%) }\end{array}$ & 100 & $65,79 *$ & $26,67^{*, \#, \delta}$ & 75 & 75 \\
\hline $\begin{array}{l}\text { Легка депресія, } \\
\text { частка осіб (\%) }\end{array}$ & 0 & $15,79 * *$ & $26,67 * *$ & 25 & 12,5 \\
\hline $\begin{array}{l}\text { Депресія } \\
\text { середньої } \\
\text { тяжкості, } \\
\text { частка осіб (\%) }\end{array}$ & 0 & $13,16^{* *}$ & 20 & $0^{\alpha}$ & 0 \\
\hline $\begin{array}{l}\text { Тяжка депресія, } \\
\text { частка осіб (\%) }\end{array}$ & 0 & 5,26 & $26,67 * \&$ & 0 & 12,5 \\
\hline $\begin{array}{l}\text { Когнітивно- } \\
\text { афективна } \\
\text { субшкала, бали }\end{array}$ & $1,45 \pm 0,33$ & $5 \pm 0,72 *$ & $\begin{array}{c}9,6 \pm \\
1,83^{*, \#, \&, \delta}\end{array}$ & $\begin{array}{l}3,75 \pm \\
0,48^{*}\end{array}$ & $4 \pm 1,6$ \\
\hline $\begin{array}{l}\text { Соматична } \\
\text { субшкала, бали }\end{array}$ & $1,55 \pm 0,35$ & $\begin{array}{l}4,84 \pm \\
0,65^{*}\end{array}$ & $\begin{array}{c}8,33 \pm \\
1,5^{*, \#, \&, \delta}\end{array}$ & $\begin{array}{r}4,5 \pm \\
0,96^{*}\end{array}$ & $3,88 \pm 1,13$ \\
\hline $\begin{array}{l}\text { Настрій } \\
\text { порушений, } \\
\text { частка осіб (\%) }\end{array}$ & 0 & $52,63 *$ & $73,33^{*}$ & $75^{*}$ & $62,5^{*}$ \\
\hline $\begin{array}{l}\text { Песимізм, } \\
\text { частка осіб (\%) }\end{array}$ & 25 & 47,37 & $86,67^{*, \#, \delta}$ & $75^{*}$ & 25 \\
\hline $\begin{array}{l}\text { Відчуття } \\
\text { провини, } \\
\text { частка осіб (\%) }\end{array}$ & 30 & 23,68 & 46,67 & $0^{* *, \&, \alpha, x}$ & 37,5 \\
\hline $\begin{array}{l}\text { Відчуття } \\
\text { можливого } \\
\text { покарання, } \\
\text { частка осіб (\%) }\end{array}$ & 10 & 28,95 & $46,67 * *$ & $0^{\alpha, \&}$ & 25 \\
\hline $\begin{array}{l}\text { Відраза до } \\
\text { самого себе, } \\
\text { частка осіб (\%) }\end{array}$ & 0 & $21,05^{*}$ & $46,67^{*}$ & $0^{\alpha, \&}$ & 12,5 \\
\hline $\begin{array}{l}\text { Ідеї самозвину- } \\
\text { вачення, } \\
\text { частка осіб (\%) }\end{array}$ & 20 & 42,11 & 40 & $0^{* *, a, \&}$ & 25 \\
\hline
\end{tabular}


Продовження таблиці 5

\begin{tabular}{|l|c|c|c|c|c|}
\hline $\begin{array}{l}\text { Втрата } \\
\text { працездатності, } \\
\text { частка осіб (\%) }\end{array}$ & 0 & $55,26^{*}$ & $93,33^{*, \#, \delta}$ & $100^{*, \alpha, x}$ & $37,5^{* *}$ \\
\hline $\begin{array}{l}\text { Порушення сну, } \\
\text { частка осіб (\%) }\end{array}$ & 15 & $50^{*}$ & $73,33^{*}$ & 50 & $62,5^{* *}$ \\
\hline $\begin{array}{l}\text { Відчуття } \\
\text { неспроможності, } \\
\text { частка осіб (\%) }\end{array}$ & 10 & 28,95 & $66,67 * *, \delta$ & $75^{* * \alpha}$ & 25 \\
\hline
\end{tabular}

Примітки: * - достовірна відмінність показників між досліджуваними i контрольною групами при $p<0,01$; ** - достовірна відмінність показників між досліджуваними i контрольною групами при $p<0,05$; ${ }^{\#}-$ достовірна відмінність показників між 1 i 2 групами при $p<0,05 ;$; - достовірна відмінність показників між 2 і 3 групами при $p<0,05 ;{ }^{\delta}-$ достовірна відмінність показників між 2 i 4 групами при $p<0,05 ;{ }^{\alpha}-$-остовірна відмінність показників між 1 i 3 групами при $p<0,05 ;^{x}$ - достовірна відмінність показників між 3 i 4 групами при $p<0,05$.

3 метою дослідження змін показників депресивних розладів хворих на РС залежно від ступеня їх інвалідазації за шкалою EDSS усіх обстежених поділили на групи (табл. 4). 3 легким ступенем інвалідизації вважали пацієнтів з 0-3,5 балами за шкалою EDSS, середнім - з 4,0-5,5 балами, а 3 тяжким - 3 6-9 балами.

Як видно 3 табл. 4, депресія виявлялася у обстежених не залежно від ступеня їх інвалідизації (середні бали шкали Бека, соматичної та когнітивно-афективної субшкал, частка осіб 3 порушеним настроєм були вищими порівняно 3 контрольною групою, $<<0,05)$. При середньому ступені інвалідизації виявили більше хворих з депресією різної тяжкості, відчуттям песимізму, неспроможності, відразою до самого себе, на відміну від практично здорових осіб, $<<0,05$. Також при цьому ступені інвалідизації середні бали за шкалою Бека, когнітивноафективною субшкалою, частка хворих з порушеним настроєм, відчуттям песимізму, неспроможності, відразою до самого себе були вищими, ніж у групі пацієнтів 3 легкою інвалідизацією $(\mathrm{p}<0,05)$. Частка обстежених без депресії виявилася меншою при тяжкій інвалідизації порівняно з легкою $(\mathrm{p}<0,05)$. Таким чином, прогресування неврологічного дефіциту у хворих на РС характеризувалося більш вираженими депресивними проявами.

У табл. 5 наведено результати середніх значень показників депресивних порушень обстежених залежно від типу перебігу 
хвороби. Виділили 4 типи перебігу РС: дебют, рецидивуючоремітуючий (РP РС), первинно-прогресуючий (ПП РС) та вториннопрогресуючий (ВП РС).

Як видно 3 табл. 5, при клінічному дебюті РС у обстежених спостерігали лише порушення настрою, сну та втрату працездатності ( $p<0,05$ порівняно 3 практично здоровими особами). Ці зміни, ймовірно, можна пояснити психологічною реакцією пацієнтів на повідомлення про хворобу. Не залежно від типу подальшого перебігу патологічного процесу середні бали шкали Бека, її субшкал, частки осіб з порушеним настроєм, втратою працездатності були вищими, ніж в контрольній групі, p $<0,05$. При РР РС спостерігали більшу частку хворих з депресією середньої тяжкості, а при ВП РС - 3 депресією тяжкого ступеня та відчуттям можливого покарання, на відміну від практично здорових осіб, $\mathbf{p}<0,05$. Прогресуючий перебіг (ВП РС і ПП РС) характеризувався більшою часткою пацієнтів 3 відчуттям песимізму (порівняно з контрольною групою) та втратою працездатності (порівняно 3 PР РС та дебютом захворювання), $\mathrm{p}<0,05$. При ПП РС відсутні хворі з відчуттям провини (на відміну від інших досліджуваних груп), ідеями самозвинувачення (на противагу контрольній групі, РP РС, ВП РС), відчуттям можливого покарання та відразою до самого себе (на відміну від РР РС та ВП PC), проте більше було осіб з відчуттям власної неспроможності (порівняно з практично здоровими особами та РP РС), при $\mathrm{p}<0,05$.

При ВП РС виявили вищі показники депресивної симптоматики порівняно з іншими типами перебігу РС. Про це свідчили вищі середні бали шкали Бека (порівняно з дебютом, РР РС та ПП РС), іiі субшкал, менша частка осіб без депресії та більша 3 відчуттям песимізму (ніж при РP РС та дебюті), більша частка хворих 3 тяжкою депресією (порівняно з ПП РС) і відчуттям неспроможності (на відміну PP PC), при $\mathrm{p}<0,05$. Наявність гірших показників депресії у обстежених з ВП РС підтверджено прямим кореляційним зв'язком між середнім балом шкали Бека та часткою хворих 3 цим перебігом $(\mathrm{r}=0,36, \mathrm{p}<0,05)$.

Таким чином, встановлено, що депресивні прояви спостерігалися уже на ранніх стадіях захворювання, при будь-якому типі перебігу та ступені інвалідизації пацієнтів з РС.

Отримані результати дослідження доповнюють сучасні роботи щодо особливостей депресивних розладів у хворих на РС. Підтверджено дані літератури, що депресія зустрічається у близько 
половини пацієнтів з $\mathrm{PC}^{15}$. Попри те, що серед обстежених більшість складали особи 3 легкою депресією $(18,46 \%, \mathrm{p}<0,01$ проти контрольної групи), у 10,77\% пацієнтів відзначалися суїцидальні думки ( $<<0,05$ проти контрольної групи). Це узгоджується з результатами інших досліджень, які свідчать, що кількість осіб з суїцидальними нахилами є більшою при РС, ніж у загальній популяції ${ }^{16}$.

Використання шкали-опитувальника Бека дозволяє отримати інформацію про наявність депресивних проявів, ступінь тяжкості депресії та визначити основні симптоми. Показано, що найчастіше в обстежених спостерігалися такі симптоми, як втомлюваність, втрата працездатності, порушення настрою та сну, відчуття песимізму, незадоволеності, дратівливості, нерішучості і неспроможності.

Спробували 3'ясувати, чи депресивні симптоми при $\mathrm{PC} \epsilon$ наслідком патологічного процесу або ж психологічної реакції на саму хворобу. Виявили, що депресивні прояви зустрічалися незалежно від тривалості, перебігу РС та ступеня інвалідизації пацієнтів (середні бали шкали Бека були вищими порівняно з контрольною групою, $\mathrm{p}<0,05)$. Подібні результати були отримані Mrabet S. et al. $(2014)^{17}$. Це дозволило припустити, що наявність депресивних розладів у хворих на РС є наслідком патологічного процесу.

Прогресування захворювання також супроводжувалося наростанням депресивних проявів, що узгоджується 3 даними інших досліджень $^{18}$. На це вказувало, по-перше, те, що кількість пацієнтів 3 депресією середньої тяжкості була більшою при тривалості РС

${ }^{15}$ Patten S.B., Marrie R.A., Carta M.G. Depression in multiple sclerosis. Int Rev Psychiatry. 2017. Vol. 29(5). P. 463.

Depression and Suicidality in Multiple Sclerosis: Red Flags, Management Strategies, and Ethical Considerations / R. Kalb et al. Curr Neurol Neurosci Rep. 2019. Vol. 19(10). P. 77.

16 Старинець Н.Г. Фактори суїцидальності при множинному склерозі. Міжнародний неврологічний журнал. 2013. № 6(60). С. 60.

Association between suicide and multiple sclerosis: An updated meta-analysis / Q. Shen et al. Mult Scler Relat Disord. 2019. Vol. 34. P. 83.

Depression and Suicidality in Multiple Sclerosis: Red Flags, Management Strategies, and Ethical Considerations / R. Kalb et al. Curr Neurol Neurosci Rep. 2019. Vol. 19(10). P. 77.

Suicidal ideation, anxiety, and depression in patients with multiple sclerosis / C.B. Tauil et al. Arq Neuropsiquiatr. 2018. Vol. 76(5). P. 299;

${ }_{17}$ Depression in multiple sclerosis / S. Mrabet, N. Ben Ali, M. Kchaou, S. Belal. Rev Neurol (Paris). 2014. Vol. 170(11). P. 702.

18 Шмидт Т.Е., Яхно Н.Н. Рассеяный склероз. Москва : Медпресс-информ, 2012. C. 62.

Solaro C., Gamberini G., Masuccio F.G. Depression in Multiple Sclerosis: Epidemiology, Aetiology, Diagnosis and Treatment. CNS Drugs. 2018. Vol. 32(2). P. 130. 
5-10 років, на відміну від контрольної групи та обстежених 3 тривалістю хвороби до одного року $(\mathrm{p}<0,05)$. При тривалості патологічного процесу понад 5 років частка обстежених з відчуттям песимізму була більшою, ніж при тривалості до року, а за наявності хвороби 5-10 років переважали особи 3 розладами настрою порівняно 3 тривалістю $1-5$ років $(\mathrm{p}<0,05)$. Частка пацієнтів 3 порушеними соціальними зв'язками була вищою при тривалості РС понад 10 років, ніж до року $(\mathrm{p}<0,05)$.

По-друге, при середньому ступені інвалідизації обстежених середні бали за шкалою Бека, когнітивно-афективною субшкалою, частка осіб 3 порушеним настроєм, відчуттям песимізму, неспроможності, відразою до самого себе були вищими, ніж у групі пацієнтів 3 легкою інвалідизацією $(\mathrm{p}<0,05)$, а частка хворих без депресії виявилася меншою при тяжкій інвалідизації порівняно з легкою $(\mathrm{p}<0,05)$. По-третє, ВП РС і ПП РС характеризувався більшою часткою пацієнтів з втратою працездатності (порівняно 3 РP РС та дебютом захворювання), а при ПП РС більше було хворих 3 відчуттям власної неспроможності (порівняно 3 практично здоровими особами та РP РС), $\mathrm{p}<0,05$. Також при ВП РС виявили вищі показники депресивної симптоматики порівняно 3 іншими типами перебігу РС. Про це свідчили вищі середні бали шкали Бека (порівняно з дебютом, РР РС та ПП РС), iї субшкал, менша частка осіб без депресії та більша з відчуттям песимізму (ніж при РР РС та дебюті), більша частка хворих з тяжкою депресією (порівняно з ПП РС) і відчуттям неспроможності (на відміну РР РС), p<0,05.

При клінічному дебюті РС у обстежених спостерігали лише порушення настрою, сну та втрату працездатності ( $<<0,05$ порівняно 3 практично здоровими особами). Ці зміни, ймовірно, можна пояснити психологічною реакцією пацієнтів на повідомлення про хворобу.

Таким чином, депресія є одним з важливих клінічних синдромів PC, який зумовлює погіршення функціонування хворих.

\section{ВИСНОВКИ}

1. Депресивні порушення різного ступеня тяжкості були виявлені у 41,54\% хворих на РС. Серед цих пацієнтів найбільшу частку складали особи 3 легкою депресією. Найчастіше в обстежених спостерігалися такі симптоми, як втомлюваність, втрата працездатності, порушення настрою та сну, відчуття песимізму, незадоволеності, дратівливості, нерішучості, неспроможності. 
2. Депресивні прояви відзначалися при РС не залежно від тривалості, перебігу захворювання та ступеня інвалідизації обстежених. Зростання тривалості хвороби, ступеня інвалідизації і ВП РС характеризувалися гіршими показниками депресивної симптоматики. У дебюті РС спостерігалося лише погіршення настрою, сну та працездатності, проте вже протягом першого року патологічного процесу показники депресії були вищими, ніж у практично здорових осіб $(\mathrm{p}<0,05)$.

3. Отримані дані свідчать про те, що депресія $є$ наслідком патологічного процесу центральної нервової системи та проявом PC, а не коморбідним станом. Депресивні розлади як психологічна реакція на повідомлення про хворобу ймовірно відзначаються при клінічному дебюті РС.

\section{АНОТАЦІЯ}

Вивчали особливості депресивних розладів у хворих на розсіяний склероз залежно від тривалості, перебігу захворювання та ступеня інвалідизації пацієнтів. Обстежено 65 пацієнтів 3 достовірним діагнозом розсіяного склерозу згідно 3 критеріями Мак Дональда 2010, яким проводили загальноклінічне, неврологічне дослідження, оцінювали вираженість депресивних проявів за шкалою-опитувальником депресії Бека. Результати порівнювали 3 показниками 20-ти практично здорових осіб контрольної групи.

Депресивні порушення різного ступеня тяжкості були виявлені у 41,54\% хворих на розсіяний склероз. Серед цих пацієнтів найбільшу частку складали особи з легкою депресією. Найчастіше в обстежених спостерігалися такі симптоми, як втомлюваність, втрата працездатності, порушення настрою та сну, відчуття песимізму, незадоволеності, дратівливості, нерішучості, неспроможності. Виявлено наростання показників депресивних проявів при збільшенні тривалості хвороби, ступеня інвалідизації і вториннопрогресуючому перебігу розсіяного склерозу. У дебюті захворювання спостерігалося лише погіршення настрою, сну та працездатності, проте уже протягом першого року патологічного процесу показники депресії були вищими, ніж у практично здорових осіб $(p<0,05)$. Таким чином, депресивні порушення частий синдром при розсіяному склерозі, який спостерігається не залежно від тривалості та перебігу захворювання, а також ступеня інвалідизації пацієнтів. 


\section{ЛІТЕРАТУРА}

1. Данилова М.В. Депрессивные расстройства у больных рассеянным склерозом (Обзор литературы). Украӥнський вісник психоневрологіï. 2012. Том 20, Вип. 1 (70). С. 55-58. URL: http://uvnpn.com.ua/ upload/iblock/6e0/6e08d5139068d33d0f9b483ed0318ca3.pdf.

2. Старинець Н.Г. Оцінка емоційно-особистісних характеристик у хворих на множинний склероз. Украӥнський неврологічний журнал. 2011. № 1(18). С. 66-69.

3. Старинець Н.Г. Фактори суїцидальності при множинному склерозі. Міжнародний неврологічний журнал. 2013. № 6(60). C. 60-64. URL: http://nbuv.gov.ua/UJRN/Mnzh_2013_6_9.

4. Шмидт Т.Е., Яхно Н.Н. Рассеяный склероз. Москва : Медпресс-информ, 2012. 272 с.

5. Arnason B., Fredrikson S. Cognition in Multiple Sclerosis. Proceedings of the MS Forum Modern Management Workshop. Budapest. 2008. 52 p.

6. Association between suicide and multiple sclerosis: An updated meta-analysis / Q. Shen et al. Mult Scler Relat Disord. 2019. Vol. 34. P. 83-90. https://doi: 10.1016/j.msard.2019.06.012.

7. Chiaravalotti N.D., DeLuca J. Когнитивные нарушения при рассеянном склерозе. The Lancet neurology Ukrainian edition. 2009. № 2(11). C. 34-49.

8. Depression and Suicidality in Multiple Sclerosis: Red Flags, Management Strategies, and Ethical Considerations / R. Kalb et al. Curr Neurol Neurosci Rep. 2019. Vol. 19(10). P. 77. https://doi: 10.1007/ s11910-019-0992-1.

9. Depression in multiple sclerosis / S. Mrabet, N. Ben Ali, M. Kchaou, S. Belal. Rev Neurol (Paris). 2014. Vol. 170(11). P. 700-702. https://doi: 10.1016/j.neurol.2014.07.017.

10. Disability worsening among persons with multiple sclerosis and depression: A Swedish cohort study / S. Binzer et al. Neurology. 2019. Vol. 93(24). e2216-e2223. https://doi: 10.1212/WNL.0000000000008617.

11. Feinstein A., Pavisian B. Multiple sclerosis and suicide. Mult Scler. 2017. Vol. 23(7). P. 923-927. https://doi: 10.1177/1352458517702553.

12. Multiple sclerosis and risk of attempted and completed suicide a cohort study / P. Brenner et al. Eur J Neurol. 2016. Vol. 23(8). P. 1329-1336. https://doi: 10.1111/ene.13029.

13. Neuropsychiatric Symptoms of Multiple Sclerosis: State of the Art / C. Silveira et al. Psychiatry Investig. 2019. Vol. 16(12). P. 877-888. https://doi:10.30773/pi.2019.0106. 
14. Patten S.B., Marrie R.A., Carta M.G. Depression in multiple sclerosis. Int Rev Psychiatry. 2017. Vol. 29(5). P. 463-472. https://doi: 10.1080/09540261.2017.1322555.

15. Prevalence of depression and anxiety in Multiple Sclerosis: A systematic review and meta-analysis / R.E. Boeschoten et al. J Neurol Sci. 2017. Vol. 372. P. 331-341. https://doi: 10.1016/j.jns.2016.11.067.

16. Siegert R.J, Abernethy D.A. Depression in multiple sclerosis: a review. J Neurol Neurosurg Psychiatry. 2005. Vol.76. P. 469-475. https://doi: 10.1136/jnnp.2004.054635.

17. Solaro C., Gamberini G., Masuccio F.G. Depression in Multiple Sclerosis: Epidemiology, Aetiology, Diagnosis and Treatment. CNS Drugs. 2018. Vol. 32(2). P. 117-133. https://doi: 10.1007/s40263018-0489-5.

18. Suicidal ideation, anxiety, and depression in patients with multiple sclerosis / C.B. Tauil et al. Arq Neuropsiquiatr. 2018. Vol. 76(5). P. 296-301. https://doi: 10.1590/0004-282X20180036.

19. The incidence and prevalence of psychiatric disorders in multiple sclerosis: A systematic review / R.A. Marrie et al. Mult Scler. 2015. Vol. 21(3). P. 305-317. https://doi:10.1177/1352458514564487.

\section{Information about the authors:}

Nehrych T. I.,

Doctor of Medical Sciences, Professor,

Head of the Department of Neurology Danylo Halytsky Lviv National Medical University

69, Pekarska str., Lviv, 79010, Ukraine

Kyryliuk S. Ya., Candidate of Medical Sciences, Neuropathologist, Municipal non-profit enterprise of the Lviv Regional Council "Lviv Regional Clinical Hospital" 7 Chernihivska str., Lviv, 79000, Ukraine 